\title{
Biological Activities of Water and Ethanol Extracts from Two Varieties of Rubus coreanus Miquel Fruits
}

\section{- Research Note -}

\author{
Yu Yin and Myeong-Hyeon Wang ${ }^{\dagger}$ \\ Department of Medical Biotechnology, College of Biomedical Science, \\ Kangwon National University, Gangwon 200-701, Korea
}

\begin{abstract}
The potential biological activities of water and ethanol extracts from two varieties of Rubus coreanus Miquel fruits produced in the Gochang-gun (GR) and Hoengseong-gun (HR) regions of Korea were examined. The hydroxyl radical $(\cdot \mathrm{OH})$ scavenging activity, reducing power, lipid peroxidation inhibitory activity, and antiproliferative activity on cancer cells by these extracts were examined, and $\alpha$-amylase and $\alpha$-glucosidase inhibition assays were also performed. The EtOH extract from GR showed high hydroxyl radical scavenging activity $\left(\mathrm{EC}_{50}=119.47\right.$ $\pm 5.13 \mu \mathrm{g} / \mathrm{mL}$ ), lipid peroxidation inhibitory activity $\left(E_{50}=213.45 \pm 3.14 \mu \mathrm{g} / \mathrm{mL}\right)$ and a concentration dependence, with OD values ranging from 0.15 to $0.56(50$ to $200 \mu \mathrm{g} / \mathrm{mL})$, for reducing power. The EtOH extract from GR has the highest antiproliferative activities on MDA-MB-231 and HepG2 cancer cells among four extracts. Meanwhile, all extracts showed certain $\alpha$-amylase and $\alpha$-glucosidase inhibition activities. These results indicate that extracts from two varieties of $\boldsymbol{R}$. coreanus fruits have significant antioxidant, anti-diabetic and anti-tumorigenic activities, which suggest these extracts could be a potential source for pharmaceutical.
\end{abstract}

Key words: antioxidant activity, anti-diabetes activity, anticancer activity, Rubus coreanus, extract

\section{INTRODUCTION}

Strong oxidants like the various reactive oxygen species (ROS) can damage molecules and the cell structures (1). The hydroxyl radical $(\cdot \mathrm{OH})$ is the neutral form of the hydroxide ion and is a kind of free radical belongs to ROS. Lipid peroxides produced from unsaturated fatty acids via radicals cause cytotoxicity and promote the formation of additional free radicals in the manner of a chain reaction (2). The formation of cancer cells in the human body can be directly induced by free radicals (3).

Diabetes mellitus, often referred to simply as diabetes, is a syndrome of disordered metabolism, due to a combination of hereditary and environmental causes, resulting in abnormally high blood sugar levels (hyperglycemia). Diabetes develops due to either a diminished production of insulin (Type 1) (4) or resistance to insulin's effects (Type 2) (5). One therapeutic approach for treating diabetes is to decrease postprandial hyperglycemia. The absorption of glucose can be retarded by inhibiting the carbohydrate-hydrolyzing enzyme $\alpha$-glucosidase in the digestive tract. Inhibitors of $\alpha$-glucosidase delay carbohydrate digestion and prolong overall carbohydrate digestion time, causing a reduction in the rate of glucose absorption and, consequently, blunting the postprandial plasma glucose rise (6). In the human diet, starch is often the main source of exogenous glucose that appears in the blood circulation postprandially (7). It has been reported that large differences can be found in the postprandial rise in blood glucose and insulin levels in response to different starch-rich foods containing the same amounts of starch (8). $\alpha$-Amylase breaks down starch into sugar. Amylase is present in human saliva, where the chemical process of digestion begins.

Cancer is a class of diseases in which a group of cells display uncontrolled growth, invasion that intrudes upon and destroys adjacent tissues. Human breast and liver cancer are the two cancer-prone in popular. The fruit of Rubus coreanus Miquel contains numerous active components, including gallic acid, protocatechuic acid, vanillic acid, syringic acid, and salicylic acid (9), and is used as a general tonic and an herbal drug to treat impotence, spermatorrhea, enuresis, asthma, allergic disease, and fatigue (10). In this study, we collected two varieties of $R$. coreanus produced in the Gochang-gun (GR) and Hoengseong-gun (HR) regions of Korea. This study evaluated the biological activities, including the antioxidant, anti-diabetic, and anticancer activities, of water and ethanol extracts from $R$. coreanus varieties collected from the Gochang-gun and Hoengseong-gun areas. 


\section{MATERIALS AND METHODS}

\section{Preparation of extracts}

Two varieties of $R$. coreanus were harvested from the Gochang-gun (GR) and Hoengseong-gun (HR) regions of Korea. Fruits of $R$. coreanus were freeze-dried and powdered, and $100 \mathrm{~g}$ of the powder were refluxed with ethanol $(\mathrm{EtOH})$ or water $(\mathrm{w} / \mathrm{v}=1: 20)$ for three days at room temperature. The mixtures were filtered and evaporated under vacuum.

\section{Cell lines and culture medium}

MDA-MB-231 cells (human breast carcinoma cell line) and HepG2 cells (human liver carcinoma cell line) were purchased from a Korean cell line bank. NCI-N87 cells were cultured in RPMI 1640, supplemented with $10 \%$ (v/v) Fetal Bovine Serum (FBS) [Hyclone, Logan, IL, USA], $100 \mathrm{U} / \mathrm{mL}$ Penicillin-Streptomycin Solution (Hyclone). HepG2 cells were cultured in DEME, supplemented with $10 \%(\mathrm{v} / \mathrm{v})$ Fetal Bovine Serum (FBS) [Hyclone], $100 \mathrm{U} / \mathrm{mL}$ Penicillin-Streptomycin Solution (Hyclone).

\section{Hydroxyl radical scavenging assay}

The Fenton reaction mixture consisted of $200 \mu \mathrm{L}$ of $\mathrm{FeSO}_{4} \cdot 7 \mathrm{H}_{2} \mathrm{O}(10 \mathrm{mM})$, EDTA $(10 \mathrm{mM})$ and 2-deoxyribose $(10 \mathrm{mM}) .200 \mu \mathrm{L}$ sample and $1 \mathrm{~mL}$ of $0.1 \mathrm{M}$ phosphate buffer ( $\mathrm{pH}$ 7.4) were added to make up a total volume of $1.8 \mathrm{~mL}$. Thereafter, $200 \mu \mathrm{L}$ of $10 \mathrm{mM} \mathrm{H} \mathrm{H}_{2} \mathrm{O}_{2}$ was added and the reaction mixture was incubated at $37^{\circ} \mathrm{C}$ for $4 \mathrm{hr}$. After incubation, $1 \mathrm{~mL}$ of $2.8 \% \mathrm{TCA}$ and $1 \mathrm{~mL}$ of $1 \%$ TBA were added and the mixture was placed in boiling water for $10 \mathrm{~min}$. The sample was centrifuged (5 min, $300 \mathrm{rpm}$ ) and the absorbance was measured at $532 \mathrm{~nm}$. Each assay was performed in triplicate. The hydroxyl radical scavenging activity was calculated according to the following equation:

Scavenging activity $(\%)=\left(1-\left(\mathrm{A}_{1}-\mathrm{A}_{2}\right) / \mathrm{A}_{0}\right) \times 100 \%$ where $\mathrm{A}_{0}$ was the absorbance of the control (blank), $\mathrm{A}_{1}$ was the absorbance in the presence of sample, and $A_{2}$ was the absorbance without 2-deoxyribose (11).

Measurement of lipid peroxidation inhibitory activity

Liposome sample (egg lecithin $6 \mathrm{mg} / \mathrm{mL}$ phosphate buffer, $\mathrm{pH}$ 7.4) was sonicated using an Ultrasonicator for $1 \mathrm{hr}$. Then $0.1 \mathrm{~mL}$ of sample was dissolved in methanol at different concentrations and added to $0.5 \mathrm{~mL}$ of the liposome mixture (12). The control was made with $0.1 \mathrm{~mL}$ methanol and without the test samples. Lipid peroxidation was induced by adding $10 \mu \mathrm{L}$ of $\mathrm{FeCl}_{3}(200$ $\mathrm{mM})$ and $10 \mu \mathrm{L}$ of ascorbic acid $(200 \mathrm{mM})$. After incubating for $1 \mathrm{hr}$ at $37^{\circ} \mathrm{C}$, the reaction was stopped by adding $2 \mathrm{~mL}$ of $0.25 \mathrm{~N} \mathrm{HCl}$ containing $15 \%$ trichloroacetic acid (TCA) and $0.375 \%$ TBA (thiobarbituric acid).
The reaction mixture was boiled for $15 \mathrm{~min}$, cooled and centrifuged, and the absorbance of the supernatant was measured at $532 \mathrm{~nm}$. The blank consisted of all the reagents without the lipid. The lipid peroxidation inhibitory activity was calculated as

Inhibitory activity $(\%)=(1-$ absorbance of sample/ absorbance of control) $\times 100$.

The lipid peroxidation inhibitory activity of BHT was also assayed for comparison. The $\mathrm{EC}_{50}(50 \%$ of the radicals scavenged by the test sample) values were also determined, with the result that the lower the $\mathrm{EC}_{50}$ value, the higher the antioxidant activity.

\section{Reducing power assay}

Sample solution $(1 \mathrm{~mL})$ was mixed with $2.5 \mathrm{~mL}$ of $0.2 \mathrm{M}$ (pH 6.6) phosphate buffer and $2.5 \mathrm{~mL}$ of $1 \%$ potassium ferricyanide $\left(\mathrm{K}_{3} \mathrm{Fe}(\mathrm{CN})_{6}\right)$, then incubated at $50^{\circ} \mathrm{C}$ for $20 \mathrm{~min}$. Then $2.5 \mathrm{~mL}$ of $10 \%$ trichloroacetic acid (TCA) was added to the mixture, followed by centrifugation at $3000 \mathrm{rpm}$ for $15 \mathrm{~min}$. The upper layer of solution $(2.5 \mathrm{~mL})$ was mixed with an equal volume of water and $0.5 \mathrm{~mL}$ of ferric chloride $\left(\mathrm{FeCl}_{3}\right)$ and the absorbance was measured photometrically at $700 \mathrm{~nm}$ (13). The reducing power tests were run in triplicate. Increase in absorbance of the reaction indicated the reducing power of samples. $\alpha$-Tocopherol was used as a positive control.

\section{$\alpha$-Amylase inhibition assay}

Twenty $\mu \mathrm{L}$ of $\alpha$-amylase $(0.05 \mathrm{U} / \mu \mathrm{L})$ was premixed with $20 \mu \mathrm{L}$ of sample and $250 \mu \mathrm{L}$ of $2 \%$ starch solution in $0.1 \mathrm{M}$ sodium phosphate buffer $(\mathrm{pH}$ 6.9) was added as a substrate to start the reaction. The reaction was carried out at $37^{\circ} \mathrm{C}$ for $10 \mathrm{~min}$ and terminated by the addition of $200 \mu \mathrm{L}$ of DNS reagent (1\% 3,5-dinitrosalicylic acid and $12 \%$ sodium potassium tartrate in $0.4 \mathrm{M}$ $\mathrm{NaOH}$ ). The reaction mixture was heated for $15 \mathrm{~min}$ at $100^{\circ} \mathrm{C}$ and then diluted with $5 \mathrm{~mL}$ of distilled (14). $\alpha$ Amylase activity was determined by measuring absorbance at $540 \mathrm{~nm}$. IR $=\left(1-\left(\mathrm{A}_{\mathrm{i}}-\mathrm{A}_{\mathrm{iB}}\right) /\left(\mathrm{A}_{0}-\mathrm{A}_{0 \mathrm{~B}}\right)\right) \times 100 \%$; $A_{i}$ is the $A_{540}$ of sample reactive solution, $A_{0}$ is the $A_{540}$ of control reactive solution, $A_{i B}$ is the blank of sample and $A_{0 B}$ is the blank of control.

\section{a-Glucosidase inhibition assay}

One hundred microliters of $3 \mathrm{mM}$ p-nitrophenyl $\alpha-\mathrm{D}^{-}$ glucopyranoside in $0.1 \mathrm{M}$ sodium phosphate buffer $(\mathrm{pH}$ 6.9) was added as a substrate to the mixture of $50 \mu \mathrm{L}$ of $\alpha$-glucosidase $(0.3 \mathrm{U} / \mathrm{mL})$ and $50 \mu \mathrm{L}$ of sample to start the reaction. The reaction was conducted at $37^{\circ} \mathrm{C}$ for $15 \mathrm{~min}$ and stopped by the addition of $750 \mu \mathrm{L}$ of $0.1 \mathrm{M} \mathrm{Na}_{2} \mathrm{CO}_{3}$. $\alpha$-Glucosidase activity was assessed by measuring the release of p-nitrophenol from p-nitrophenyl $\alpha$-D-glucopyranoside at $400 \mathrm{~nm}$ (15). 


\section{Antiproliferative activity on cancer cells}

MDA-MB-231 and HepG2 cells growth inhibition activity was measured using the MTT assay. Tumor cells were seeded in a 96-well plate at a concentration of $2 \times 10^{5}$ cells $/ \mathrm{mL}$. After $4 \mathrm{hr}$ at $37^{\circ} \mathrm{C}$, in a humidified atmosphere of $5 \% \mathrm{CO}_{2}$, all extracts were added to the wells at a concentration of $100 \mu \mathrm{g} / \mathrm{mL}$. Negative and positive control was added with distilled water and 10 $\mu \mathrm{g} / \mathrm{mL}$ fluorouracil (5-FU), respectively. The cells were incubated for an additional $48 \mathrm{hr}$ at $37^{\circ} \mathrm{C}$. An MTT stock solution $(50 \mu \mathrm{L} ; 2 \mathrm{mg} / \mathrm{mL}$ in PBS) was added to each well for a total reaction volume of $250 \mu \mathrm{L}$. After incubating for $4 \mathrm{hr}$ in a humidified atmosphere of $5 \% \mathrm{CO}_{2}$ at $37^{\circ} \mathrm{C}$, the supernatants of each well were separated. The formazan crystals in each well were dissolved in $150 \mu \mathrm{L}$ of DMSO. The amount of purple formazan was determined by measuring the absorbance at $540 \mathrm{~nm}$ after $15 \sim 20 \mathrm{~min}$. For treated cells, viability was expressed as a percentage of control cells. All determinations were carried out in triplicate (16). Cell death $(\%)=\left(\mathrm{A}_{0}-\mathrm{A}_{\mathrm{t}}\right) /$ $A_{0} \times 100 \% ; A_{t}$ is the $A_{540}$ of test sample or positive control reactive solution, $A_{0}$ is the $A_{540}$ of negative control reactive solution.

\section{Statistical analysis}

Means were calculated from three replications for each experiment. Data were analyzed employing SPSS v13.0 (Statistical Package for the Social Sciences, Chicago, IL, USA). Tukey's test was used to determine the significance of difference $(p<0.05)(17)$.

\section{RESULTS AND DISCUSSION}

\section{Hydroxyl radical scavenging activity}

As shown in Table 1, EtOH extract from GR showed the highest scavenging activity among 4 extracts, its $\mathrm{EC}_{50}$ is $119.47 \pm 5.13 \mu \mathrm{g} / \mathrm{mL}$. The $\mathrm{EC}_{50}$ of $\mathrm{EtOH}$ extract from $\mathrm{HR}$ is $149.20 \pm 6.85 \mu \mathrm{g} / \mathrm{mL}$, meanwhile water ex- tracts from two varieties of $R$. coreanus have no effects on hydroxyl radical scavenging activity. $\alpha$-Tocopherol was used as a positive control $\left(\mathrm{EC}_{50}=7.61 \pm 2.31 \mu \mathrm{g} /\right.$ $\mathrm{mL}$ ). These results suggest that low polarity compounds with hydroxyl radical scavenging activity existed in $R$. coreanus. Phenolic compounds are found in both edible and inedible plants, and they have been reported to have multiple biological effects, including antioxidant activity. The antioxidant activity of phenolic compounds is mainly due to their redox properties, which can play an important role in absorbing and neutralizing free radicals, quenching singlet and triple oxygen, or decomposing peroxides (18).

\section{Lipid peroxidation inhibitory activity}

To evaluate the antioxidant activity of extracts and BHT (to inhibit lipid peroxidation in biological systems), a liposome model system was used. Thiobarbituric acid reacts with malondialdehyde (MDA) to form a diadduct, a pink chromogen, which can be detected spectrophotometrically at $532 \mathrm{~nm}$. Malondialdehyde is the major product of lipid peroxidation and has been studied widely as an index of lipid peroxidation and as a marker for oxidative stress (19). The lipid peroxidation inhibitory activity of extracts and BHT is given in Table 1. The inhibitory activity of EtOH extract from GR $(213.45 \pm 3.14 \mu \mathrm{g} / \mathrm{mL})$ was higher compared with other extracts. $\mathrm{EC}_{50}$ values for water extract from GR, water extract and EtOH extract from HR were $346.17 \pm 4.55$, $345.78 \pm 3.14$, and $273.65 \pm 2.65 \mu \mathrm{g} / \mathrm{mL}$, respectively. The lower the $\mathrm{EC}_{50}$ value, the higher the antioxidant activity. Generally, phenolics and flavonoids inhibit the lipid peroxidation by chain termination through scavenging the peroxyl radicals (20). Thus, maybe the EtOH extract from GR has the abundant phenolic and flavonoid compounds. The mechanism of lipid peroxidation in this study might be through electron donation or by scaveng-

Table 1. Hydroxyl radical scavenging activity and lipid peroxidation inhibitory activity of extracts from $R$. coreanus fruits produced in different areas

\begin{tabular}{lccc}
\hline Sample & Extract & $\begin{array}{c}\text { Hydroxyl radical scavenging activity } \\
\left(\mathrm{EC}_{50}: \mu \mathrm{g} / \mathrm{mL}\right)\end{array}$ & $\begin{array}{c}\text { Lipid peroxidation inhibitory activity } \\
\left(\mathrm{EC}_{50}: \mu \mathrm{g} / \mathrm{mL}\right)\end{array}$ \\
\hline \multirow{2}{*}{$\mathrm{GR}^{1)}$} & Water ext. & $\mathrm{NE}^{4)}$ & $346.17 \pm 4.55^{\mathrm{c}}$ \\
& EtOH ext. & $119.47 \pm 5.13^{\mathrm{b}}$ & $213.45 \pm 3.14^{\mathrm{b}}$ \\
\hline \multirow{2}{*}{$\mathrm{HR}^{2)}$} & Water ext. & $\mathrm{NE}$ & $345.78 \pm 3.14^{\mathrm{c}}$ \\
& EtOH ext. & $149.20 \pm 6.85^{\mathrm{c}}$ & $273.65 \pm 2.65^{\mathrm{b}}$ \\
\hline$\alpha-$ Tocopherol $^{\mathrm{B}} \mathrm{CT}^{3)}$ & & $7.61 \pm 2.31^{\mathrm{a}}$ & - \\
\hline
\end{tabular}

\footnotetext{
${ }^{1)} \mathrm{GR}: R$. coreanus produced in the Gochang-gun region of Korea.

${ }^{2)} \mathrm{HR}$ : $R$. coreanus produced in the Hoengseong-gun region of Korea.

${ }^{3)}$ BHT: butylated hydroxytoluene.

${ }^{4)} \mathrm{NE}$ : no effect. ${ }^{5)}-$ : Not detected.

Values not followed by the same superscript letter are significantly different $(p<0.05)$.
} 


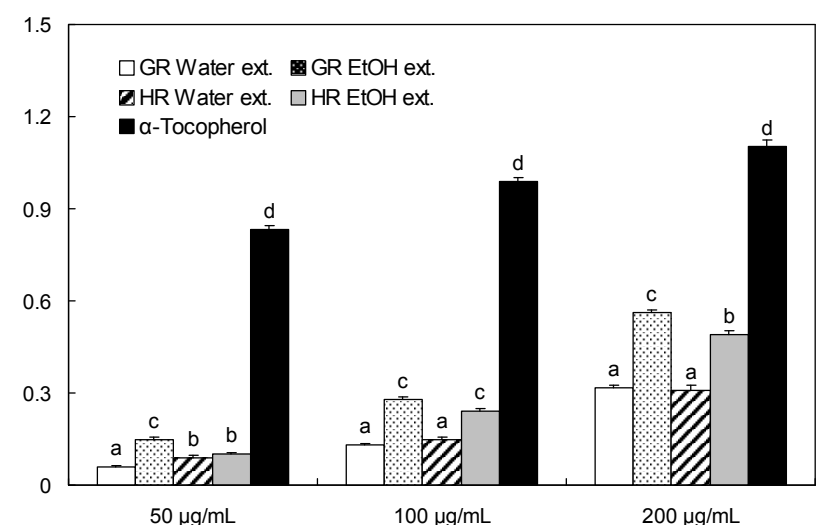

Fig. 1. Reducing power assay of extracts from $R$. coreanus fruits produced in different areas. $\alpha$-Tocopherol was used as a positive control and values are expressed as mean $\pm \mathrm{SD}$ $(n=3)$. GR, HR: Refer to Table 1. Bars labeled with different letters indicate significant difference at $\mathrm{p}<0.05$.

ing the peroxyl radicals.

\section{Reducing activity}

The reducing activity of the $R$. coreanus increased with increasing sample concentration (Fig. 1). EtOH from GR has the strongest reducing power activity in dose-dependent manner among four extracts. Reducing power activity is associated with the presence of reductones (21), which have been shown to exert an antioxidant effect by donating a hydrogen atom and breaking the free radical chain. Reductones are reported to react with certain peroxide precursors, which prevent peroxide formation (22). In this study, the EtOH extract from GR had high reducing activity, suggesting that the reducing activity of the fraction contributes significantly to its antioxidant effect and that there are likely some kinds of reductones in it.

\section{$\alpha$-Glucosidase and $\alpha$-amylase inhibition activities}

$\alpha$-Glucosidase and $\alpha$-amylase inhibition activities were measured in this study. Table 2 shows that all extracts have certain $\alpha$-glucosidase and $\alpha$-amylase inhibition activities. The order of $\mathrm{IC}_{50}$ value in $\alpha$-amylase assay is $\mathrm{HR}$ EtOH ext. $(978.28 \pm 4.31 \mu \mathrm{g} / \mathrm{mL})<\mathrm{HR}$ water ext. $(1071.23 \pm 5.41 \mu \mathrm{g} / \mathrm{mL})<$ GR EtOH ext. $(1224.62 \pm 7.21$ $\mu \mathrm{g} / \mathrm{mL})<$ GR water ext. $(1246.00 \pm 6.34 \mu \mathrm{g} / \mathrm{mL})$, and in $\alpha$-glucosidase is HR EtOH ext. $(154.21 \pm 8.12 \mu \mathrm{g} / \mathrm{mL})<$ GR EtOH ext. $(241.39 \pm 5.87 \mu \mathrm{g} / \mathrm{mL})<\mathrm{HR}$ water ext. $(571.24 \pm 9.13 \mu \mathrm{g} / \mathrm{mL})<$ GR water ext. $(872.36 \pm 9.12$ $\mu \mathrm{g} / \mathrm{mL}$ ), respectively. Acarbose was used as a positive control in these two inhibition assays.

Non-insulin-dependent diabetes mellitus is a heterogeneous disease with both environmental and genetic causative factors, and is characterized by hyperglycemia induced by decrease in the secretion of insulin from the pancreatic Langerhans $\beta$-cells. Inhibiting $\alpha$-amylase and $\alpha$-glucosidase are alternative therapeutic approaches for treating non-insulin diabetes mellitus, which are the key enzymes involved in starch breakdown and intestinal absorption. The digestion and uptake of carbohydrate significantly decreases with the inhibition of these enzymes, which decreases the postprandial blood glucose level in the non-insulin-dependent diabetes mellitus patients (23). Acarbose is presently used as $\alpha$-amylase and $\alpha$-glucosidase inhibitors. All extracts exhibited significant inhibition activity against $\alpha$-glucosidase and $\alpha$ amylase (Table 2). Perhaps $\alpha$-glucosidase and $\alpha$-amylase inhibitor can be isolated from $R$. coreanus fruits to treat diabetes disease.

\section{Anticancer activity}

In an anticancer activity assay, MDA-MB-231 and HepG2 cells were chosen to determine the antiproliferative activity of $R$. coreanus extracts (24). The MTT assay is a novel method of quantifying metabolically viable cells via their ability to reduce a soluble yellow tetrazolium salt to blue-purple formazan crystals (25). The crystals are thought to be produced by the mitochondrial enzyme succinate dehydrogenase, and they can be dissolved and quantified by measuring the absorbance of the resultant solution. The absorbance of the solution is related to the number of live cells. By using 96-well micro titer plates and a multiwell spectrophotometer (enzyme-linked immunosorbent assay plate reader) this assay can be semiautomated to process a large number of samples and to provide a rapid object measurement

Table 2. $\alpha$-Amylase inhibition activity and $\alpha$-glucosidase inhibition activity of extracts from $R$. coreanus fruits produced in different areas

$\left.\begin{array}{cccc}\hline \multirow{2}{*}{\text { Sample }} & \multirow{2}{*}{\text { Extract }} & \alpha \text {-Amylase inhibition activity } & \begin{array}{c}\alpha \text {-Glucosidase inhibition activity } \\ \left(\mathrm{IC}_{50}: \mu \mathrm{g} / \mathrm{mL}\right)\end{array} \\ \hline \multirow{2}{*}{\mathrm{GR}^{1)}} & \text { Water ext. } & \left.1246.00 \pm 6.34^{\mathrm{c}} / \mathrm{mL}\right)\end{array}\right)$

${ }^{1), 2)}$ Refer to Table 1 .

Values not followed by the same superscript letter are significantly different $(p<0.05)$. 
Table 3. Cytotoxicity of extracts from $R$. coreanus fruits produced in different areas on human breast cancer cells (MDA-MB-231) and human liver cancer cells (HepG2) by MTT assay

\begin{tabular}{lcrr}
\hline \multirow{2}{*}{ Sample } & \multirow{2}{*}{ Extract } & \multicolumn{2}{c}{ Cell death (\%) } \\
\cline { 3 - 4 } & & MDA-MB-231 & \multicolumn{1}{c}{ HepG2 } \\
\hline \multirow{2}{*}{ GR $^{2)}$} & Water ext. & $4.31 \pm 0.50^{\mathrm{d}}$ & $5.36 \pm 0.64^{\mathrm{c}}$ \\
& EtOH ext. & $9.21 \pm 0.67^{\mathrm{c}}$ & $10.35 \pm 2.14^{\mathrm{b}}$ \\
\hline \multirow{2}{*}{$\mathrm{HR}^{3)}$} & Water ext. & $5.20 \pm 0.57^{\mathrm{d}}$ & $6.12 \pm 3.19^{\mathrm{c}}$ \\
& EtOH ext. & $12.12 \pm 0.64^{\mathrm{b}}$ & $13.27 \pm 2.85^{\mathrm{b}}$ \\
\hline \multirow{2}{*}{ 5-FU } & & $50.33 \pm 1.07^{\mathrm{a}}$ & $51.32 \pm 1.56^{\mathrm{a}}$ \\
\hline
\end{tabular}

${ }^{1)}$ All extracts' concentration was $100 \mu \mathrm{g} / \mathrm{mL}$. 5-FU was used as a positive control $(10 \mu \mathrm{g} / \mathrm{mL})$.

${ }^{2), 3)}$ Refer to Table 1 .

Values not followed by the same superscript letter are significantly different $(\mathrm{p}<0.05)$.

of cell number. As shown in Table 3, EtOH extract from HR showed the highest cytotoxic activity among four extracts, the value of cytotoxic activity is $12.12 \pm 0.64 \%$ on MDA-MB-231 cells and $13.27 \pm 2.85 \%$ on HepG2 cells, respectively. Meanwhile, other extracts also showed certain anti-proliferation activities on two human cancer cells. However, these four extracts have no stronger anticancer activity compared to positive control (5-FU).

\section{CONCLUSION}

In conclusion, $R$. coreanus fruits could be considered as an ingredient of functional foods as well as for pharmaceutical purposes. Although biological activities value of extracts from two varieties of $R$. coreanus fruits have no significant difference, further studies on the identification of the compounds in $R$. coreanus fruits containing bioactive properties in vivo are necessary to better identify the beneficial effects.

\section{REFERENCES}

1. Liu JK, Head E, Gharib AM, Yuan WJ, Ingersell RT, Hagen TM, Cotman CW, Ames BN. 2002. Memory loss in old rats is associated with brain mitochondrial decay and RNA/DNA oxidation: Partial reversal by feeding acetyl-L-carnitine and /or R- $\alpha$-lipoic acid. Proc Natl Acad Sci USA 99: 2356-2361.

2. Choi JM, Han J, Yoon BS, Chung JH, Shin DB, Lee SK, Hwang JK, Ryang R. 2006. Antioxidant properties of tannic acid and its inhibitory effects on paraquat-induced oxidative stress in mice. Food Sci Biotechnol 15: 728-734.

3. Athukorala Y, Kim KN, Jeon YJ. 2006. Antiproliferative and antioxidant properties of an enzymatic hydrolysate from brown alga, Ecklonia cava. Food Chem Toxicol 44: 1065-1074.

4. Headig D, Tarnow L, Kuhn J, Kleesiek K, Götting C. 2008. Identification of a xylosyltransferase II gene haplotype marker for diabetic nephropathy in type 1 diabetes. Clin Chim Acta 398: 90-94.
5. Jain S, Saraf S. 2008. Type 2 diabetes mellitus - its global prevalence and therapeutic strategies. Diab Met Syndr Clin Res Rev 79: 14-27.

6. Holman RR, Turner RC, Cull CA. 1999. A randomized double-blind trial of acarbose in type 2 diabetes shows improved glycemic control over 3 years (UK Prospective diabetes study 44). Emerg Treat Tech 22: 960-964.

7. Ells LJ, Seal CJ, Kettliz B, Bal W, Mathers C. 2005. Postprandial glycaemic, lipaemic and haemostatic responses to ingestion of rapidly and slowly digested starches in healthy young women. $B r J$ Nutr 94: 948-955.

8. Wallace AJ, Monro JA, Brown RC, Frampton CM. 2008. A glucose reference curve is the optimum method to determine the glycemic glucose equivalent values of foods in humans. Nutr Res 28: 753-759.

9. Ju HK, Cho EJ, Jang MH, Lee YY, Hong SS, Park JH, Kwon SW. 2009. Characterization of increased phenolic compounds from fermented Bokbunja (Rubus coreanus Miq.) and related antioxidant activity. $J$ Pharm Biomed Anal 49: 820-827.

10. Park YS, Chang HG. 2003. Latic acid fermentation and biological activities of Rubus coreanus. Korean J Soc Agric Chem Biotechnol 46: 367-375.

11. Yin Y, Heo SI, Wang MH. 2008. Antioxidant and anticancer activities of methanol and water extracts from leaves of Cirsium japonicum. J Appl Biol Chem 51: 160-164.

12. Masao H, Yang XW, Miyashiro H, Nabma T. 1993. Inhibitory effects of monomeric and dimeric phenylpropanoids from mice on lipid peroxidation in vivo and in vitro. Phytother Res 7: 395-401.

13. Oyaizu M. 1986. Studies on products of browning reaction prepared from glucosamine. Japanese J Nutr 44: 307-315.

14. Maeda K, Kakabayashi S, Matsubara H. 1985. Complete amino acid sequence of an $\alpha$-amylase inhibitor in wheat kernel (0.19-inhibitor). Biochi Biophys Acta 828: 213-221.

15. Kim YM, Jeong YK. 2005. Inhibitory effect of pine extract on $\alpha$-glucosidase activity and postprandial hyperglycemia. Nutrition 21: 756-761.

16. Popiolkiewicz J, Polkowski K, Skierski JS, Mazurek AP. 2005. In vitro toxicity evaluation in the development of new anticancer drugs-genistein glycosides. Cancer Lett 229: $67-75$

17. Ding T, Rahman SME, Purev U, Oh DH. 2010. Modeling of Escherichia coli $\mathrm{O} 157: \mathrm{H7}$ growth at various storage temperatures on beef treated with electrolyzed oxidizing water. J Food Process Eng 97: 497-503.

18. Siriwardhana SSKW, Shahidi F. 2002. Antiradical activity of extracts of almond and its by-products. JAOSC 79: 903-908

19. Amin A, Yazdanparast R. 2007. Antioxidant and free radical scavenging potential of Achillea santolina extracts. Food Chem 104: 21-29.

20. Prasad NK, Divakar S, Shivamurthy GR, Aradhya SM. 2005. Isolation of a free radical scavenging antioxidant from water spinach (Ipomoea aquatica Forsk). J Sci Food Agric 85: 1461-1468.

21. Duh PD. 1998. Antioxidant activity of burdock (Arctium lappa Linné): its scavenging effect on free radical and active oxygen. JAOCS 75: 455-461.

22. Gordon MH. 1990. The mechanism of antioxidant action in vitro. In Food Antioxidants. Hudson BJF, ed. Elsevier, Applied Science, London, UK. p 1-18.

23. Puls W, Keup U, Krause HP, Thomas G, Hoffmeister F. 1977. Glucosidase inhibition. A new approach to the treat- 
ment of diabetes, obesity, and hyperlipoproteinaemia. Naturwissenschaften 64: 536-537.

24. Lee CL, Yang XT, Wan JMF. 2006. The culture duration affects the immunomodulatory and anticancer effect of polysaccharopeptide derived from Coriolus versicolor.
Enzyme Microb Technol 38: 14-21.

25. Yin Y, Heo SI, Roh KS, Wang MH. 2009. Biological activities of fractions from methanolic extract of Picrasma quassioides. J Plant Biol 52: 325-331.

(Received November 1, 2010; Accepted February 10, 2011) 